\title{
Changes in the development of the winter-spring phytoplankton bloom in the Bay of Calvi (NW Mediterranean) over the last two decades: a response to changing climate?
}

\author{
Anne Goffart ${ }^{1, *}$, Jean-Henri Hecq ${ }^{1}$, Louis Legendre ${ }^{2}$ \\ ${ }^{1}$ Unité d'Ecohydrodynamique, Département des Sciences de la Vie, Université de Liège, B 5, 4000 Liège, Belgium \\ ${ }^{2}$ Laboratoire d'Océanographie de Villefranche, BP 28, 06234 Villefranche-sur-Mer Cedex, France
}

\begin{abstract}
The development of the winter-spring phytoplankton bloom was investigated in the Bay of Calvi (Corsica, Ligurian Sea, northwestern Mediterranean) in 1979, 1986, 1988, 1997 and 1998. A drastic reduction of phytoplankton biomass was evidenced over the last 2 decades, in relation to longterm changes in climatic and environmental conditions. Between 1979 and 1998, the monthly averaged chlorophyll a concentrations at $1 \mathrm{~m}$ decreased by about $80 \%$ during February, March and April. Simultaneously, major changes to hydrodynamic conditions include warmer water, overall decrease of salinity at $10 \mathrm{~m}$ depth, longer periods of bright sunshine and lower wind stress. The changes in environmental conditions were large enough to affect the vertical stability of the water column during the winter-spring period and to reduce nutrient replenishment of the surface layer prior to the usual period of phytoplankton growth. Until 1986, the main factor driving nutrient replenishment was the winter upward mixing of nutrient-rich deep waters, while the progressive reduction of mixing from 1988 induced nutrient limitation of surface waters in the last decade. The following hypotheses on changes in the development of the winter-spring phytoplankton bloom are made: (1) Until 1986, phytoplankton peaks took place in relatively high-nutrient waters and were diatom-dominated. (2) Between 1986 and 1988, decreasing Si availability led to Si limitation which caused a reduction in diatom abundance. This resulted in the disappearance of the diatom-dominated pulses and in lower phytoplankton biomass and was accompanied by a shift toward non-siliceous phytoplankton. (3) In 1988, 1997 and 1998, decreasing nitrate availability led to nitrate limitation, thus explaining the progressive reduction in non-siliceous phytoplankton biomass. Other, associated changes in benthos assemblages and ichthyofauna are documented. The conclusions from the Bay of Calvi are extended to the whole western Corsican coast. This confirms that the Mediterranean reacts rapidly to external perturbations, which are driven by climate change in that particular area.
\end{abstract}

KEY WORDS: Phytoplankton bloom $\cdot$ Mediterranean ecosystem $\cdot$ Climatic change $\cdot$ Environmental change

Resale or republication not permitted without written consent of the publisher

\section{INTRODUCTION}

The Mediterranean Sea is a semi-enclosed water body where the general circulation pattern is domi-

*E-mail: a.goffart@ulg.ac.be nated by negative thermohaline circulation, which draws in nutrient-poor surface waters of Atlantic origin through the Strait of Gibraltar (e.g. Cruzado 1985, Hopkins 1985). At the scale of the whole Mediterranean basin, winter mixing provides the major nutrient input to surface waters. At regional or local scales, other fertilizing mechanisms, such as frontal systems, wind- 
induced upwelling in the slope region, river runoff and local mixing due to the breakdown of the thermocline, may also induce localized nutrient enrichment of the euphotic zone (e.g. Estrada \& Margalef 1988, Goffart et al. 1995). However, because the nutrient concentration in the Mediterranean deep-water reservoir is low compared with the remainder of the world ocean (Estrada et al. 1985), the vertical turnover is less effective in resupplying nutrients to the surface than in most other areas (Coste et al. 1972). Consequently, the trophic status of surface layers varies from mesotrophic in the northwestern Mediterranean to extremely oligotrophic in the eastern basin (e.g. Thingstad \& Rassoulzadegan 1995, Pedró-Alió et al. 1999). Average values of total primary production derived from Coastal Zone Color Scanner (CZCS) observations amount to 158 and $109 \mathrm{gC} \mathrm{m}^{-2} \mathrm{yr}^{-1}$ for the western and eastern basins, respectively (Antoine et al. 1995).

In the western basin, the vertical structure of the water column shows strong seasonality, characterized by the alternation of periods of mixing and stratification. This alternation generates major changes in the average irradiance experienced by phytoplankton and nutrient concentrations, which controls phytoplankton dynamics in terms of both community structure and productivity. Phytoplankton blooms occur in winter-spring, when the surface waters begin to stabilize and, to a lesser extent in autumn, when the thermocline disappears (reviewed in Estrada 1996). Although the magnitude of the winterspring bloom differs considerably among different areas of the western Mediterranean, maximum chlorophyll a (chl a) concentrations range from 0.7 (Garcia-Gorriz \& Carr 1999) to $4.0 \mathrm{mg} \mathrm{m}^{-3}$ (Morel \& André 1991).

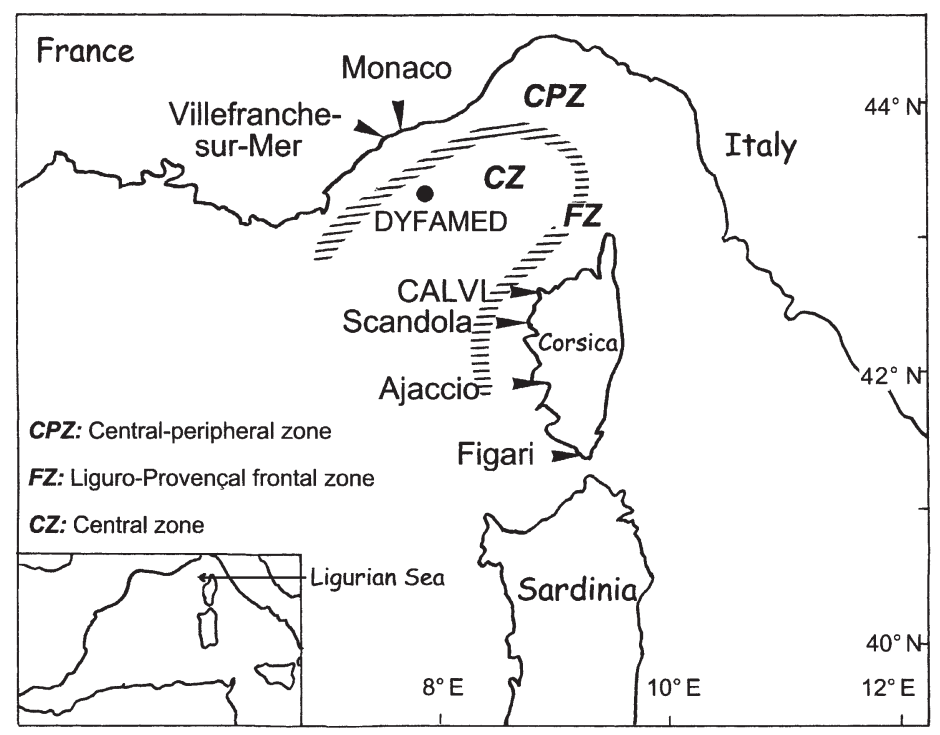

Fig. 1. Map of the Ligurian Sea (western Mediterranean) showing study site, location of stations cited in the text and schematic position of the main hydrological zones
Superimposed on the seasonal cycle, enhanced levels of phytoplankton concentration and primary production are observed throughout the year in areas where permanent frontal systems occurred. This is the case for the Ligurian Sea, a part of the LiguroProvençal basin, which includes the northwestern Corsican coasts, the French Riviera and the Provençal coasts (Pinca \& Dallo 1995). In the Ligurian Sea, the coastal cyclonic Ligurian Current organizes the hydrological structure of the basin into 3 distinct main zones (Fig. 1): the coastal-peripheral zone, the permanent Liguro-Provençal frontal zone ca. $30 \mathrm{~km}$ offshore and the central zone (Boucher et al. 1987, Sournia et al. 1990, Pinca \& Dallot 1995). The permanent frontal zone is a highly dynamic area, where a complex network of divergences brings nutrients from deep water into the euphotic zone, thus contributing to an enhancement of phytoplankton new production (e.g. Sournia et al. 1990, Goffart \& Hecq 1993, Goffart et al. 1995). As far as the pelagic ecosystem is concerned, one of the peculiarities of the Ligurian Sea is that the shelf region is more oligotrophic than the frontal and central offshore areas (e.g. Sournia et al. 1990, Goffart et al. 1995, Pinca \& Dallot 1995).

In coastal waters of the northwestern basin, the development of the winter-spring phytoplankton bloom (between January and March) is one of the most coherent seasonal features of the Mediterranean ecosystem. It is the main clue for seasonal ecosystem processes, and is such a recurrent feature that it is imprinted in the life history of ecosystem components (Duarte et al. 1999). This is the case for sardines, which spawn at the start of the phytoplankton production period (Palomera \& Olivar 1996), and for most of benthic invertebrates, which reproduce at that time of the year (López et al. 1998). During the winter-spring bloom, diatoms make up the bulk of phytoplankton, and a few species of genera Chaetoceros, Nitzschia, Rhizosolenia and Thalassiosira together with species Skeletonema costatum dominate the autotrophic community (e.g. Margalef \& Castellví 1967, Travers 1975, Grillini \& Lazzara 1980, Jacques \& Tréguer 1986, Mura et al. 1996, Estrada et al. 1999). Small flagellates and sometimes coccolithophorids may contribute to the coastal winter-spring bloom, but their contributions to total biomass vary among coastal areas (Estrada et al. 1985). Although winter presence of cyanobacteria (including prochlorophytes) has been reported in surface waters (Vaulot et al. 1990), the contribution of picophytoplankton to total autotrophic biomass is much lower than that of other groups during the winterspring period (Mura et al. 1996). 
The development of the phytoplankton winterspring bloom is characterized by interannual variability, in terms of the onset of the bloom, its duration and the magnitude of organic production (e.g. BustillosGuzmán et al. 1995, Mura et al. 1996). However, because phytoplankton dynamics during the winter-spring period is strongly controlled by the physical environment and the supply of nutrients from deep water, it follows that a similar sequence of events is repeated year after year with only small departures from the average (Margalef 1985). The pattern may have been altered in the last few years, because of changes in water characteristics of the Mediterranean, perhaps in response to human activities, or regional or global climate change (Bethoux et al. 1998, Turley 1999).

Increasing seawater temperature and salinity were observed in both the eastern and western basins. These increases are thought to be a consequence of changes in the heat and water budgets across the sea surface, which result from increased greenhouse effect and decreased freshwater input (Bethoux et al. 1990, Rohling \& Bryden 1992, Bethoux \& Gentili 1996, 1999, Roether et al. 1996). The latter include man-made changes to the freshwater input such as the damming of the Nile in Egypt and of the Ebro in Spain, that occurred in the 1960s. These have drastically reduced the flow of freshwater into the sea, which has led to a general increase in the salinity of Mediterranean seawater (Bethoux et al. 1998, Williams 1998). The consequences of these changes remain to be understood but, because temperature and salinity determine water density, there could be an alteration of water mass properties and circulation as already reported for the eastern basin by Della Vedova et al. (1995) and Roether et al. (1996).

In conjunction with the increasing trend in temperature and salinity, Bethoux et al. (1998) found that phosphate and nitrate concentrations are also increasing in deep waters of the western basin. According to these authors, because the increase in deep nutrients was not likely caused by changes in the Atlantic inflow, inputs from atmospheric and terrestrial sources (mostly agricultural run-off) may be considered responsible for it. Furthermore, many coastal and adjacent waters experience eutrophication due to high discharge of nutrients, as a consequence of agricultural and industrial practices, and increased urbanization of surrounding lands (UNEP/FAO/WHO 1996).

Because the human population in the Mediterranean basin increases exponentially (Duarte et al. 1999) and tourism is likely to increase substantially in coming years (Turley 1999), human pressure and climate change are expected to cause widespread changes in the physical and chemical characteristics of Mediterranean water masses. The consequences of the observed and predicted physical and chemical changes on the biological components of ecosystems are still largely unknown, but there is evidence that biological characteristics are already changing. Examples of ecosystem changes can be found in the eastern basin, where more than 350 species have immigrated (Por 1990, Galil 1993) after the deepening and widening of the Suez Canal (Bethoux \& Gentili 1996). In the western basin, sea meadows of Posidonia oceanica, which are a distinctive feature of the Mediterranean, and are essential spawning and feeding grounds for 100s of fish species, are being destroyed by an alien seaweed accidentally introduced from the tropics, Caulerpa taxifolia (Turley 1999). However, most of the reported changes in ecosystem components are based on either anecdotal or scattered information (Duarte et al. 1999). Moreover, the interplay between changing hydrodynamic processes and plankton dynamics is unknown, even if it is crucial for the management and protection of living resources.

The purpose of the present paper is to document the consequences of the changing Mediterranean environment on living organisms, based on unique records of phytoplankton biomass and related environmental and climatic characteristics over the last 2 decades. The data were collected in the Bay of Calvi, Corsica (Fig. 1), during the winter-spring phytoplankton bloom. Our approach is: (1) to characterize the long-term trends in the interannual variations of phytoplankton biomass and of physical and chemical characteristics of the water column and climate; (2) to propose mechanisms that explain the former by the latter; (3) to document other, associated ecological changes in the Bay of Calvi; and (4) to extend the conclusions from the Bay of Calvi to the whole Ligurian Sea.

\section{MATERIALS AND METHODS}

Sampling. Field data were collected at a fixed station in the Bay of Calvi, a low-runoff system opened to the north which has a narrow continental shelf with a steep canyon. The sampling station $\left(42^{\circ} 34^{\prime} 85^{\prime \prime} \mathrm{N}\right.$,

Table 1. Dates of the time-series in the Bay of Calvi and numbers of sampling days for biological and chemical variables

\begin{tabular}{|c|c|c|c|c|c|}
\hline \multirow[t]{2}{*}{ Year } & \multirow{2}{*}{$\begin{array}{c}\text { Sampling period } \\
\mathrm{dd} / \mathrm{mm}\end{array}$} & \multicolumn{4}{|c|}{ No. of sampling days } \\
\hline & & Chl a & Carotenoids & Nitrate & $\begin{array}{c}\text { Silicic } \\
\text { acid }\end{array}$ \\
\hline 1979 & $01 / 02-31 / 05$ & 22 & - & - & - \\
\hline 1986 & $28 / 02-02 / 05$ & 62 & - & - & - \\
\hline 1988 & $22 / 02-13 / 05$ & 48 & 48 & 50 & 50 \\
\hline \multirow[t]{2}{*}{1997} & $22 / 02-10 / 04$ & 68 & 68 & 71 & 68 \\
\hline & $29 / 05-31 / 05$ & 3 & 3 & 3 & 3 \\
\hline 1998 & $22 / 01-08 / 06$ & 70 & 70 & 93 & 93 \\
\hline
\end{tabular}


$08^{\circ} 43^{\prime} 60^{\prime \prime} \mathrm{E}$ ) is situated near the coast, in the northern part of the Bay of Calvi, and is influenced by oligotrophic waters of Atlantic origin. The depth of the station is approximately $10 \mathrm{~m}$. Sampling was conducted during 5 winter-spring periods between 1979 and 1998 (Table 1).

Water samples were collected at $1 \mathrm{~m}$ depth, at 09:00 h (local time) using a 2.51 Niskin bottle. In 1979, 22 samples were collected over the sampling period. In the following year, samples were collected daily or every second day (Table 1). In 1979 and 1986, samples were taken for chl a only and, in 1988, 1997 and 1998, for nutrients, chl a and carotenoid pigments.

Water samples for nitrate, nitrite and silicic acid $(20 \mathrm{ml})$ were immediately frozen in polyethylene flasks and stored at $-20^{\circ} \mathrm{C}$ until analysis, within $2 \mathrm{wk}$ of sampling. Samples for pigment analysis (2 to 5 l) were prefiltered through a $200 \mu \mathrm{m}$ mesh screen to remove mesozooplankton. They were immediately filtered under low vacuum pressure $(<100 \mathrm{~mm} \mathrm{Hg})$ through Whatman GF/C filters (nominal pore size $1.2 \mu \mathrm{m}$ ) in 1979 and 1986, and through Whatman GF/F filters (nominal pore size $0.7 \mu \mathrm{m}$ ) in 1988, 1997 and 1998. Filters were wrapped in aluminum foil and stored at $-20^{\circ} \mathrm{C}$, and analyzed within $2 \mathrm{wk}$ of sampling.

Nutrients. Nutrients were determined on a Technicon AutoAnalyser II (precision $\pm 25 \mathrm{nM}$ ). Nitrate and nitrite were analyzed according to working procedures of Tréguer \& Le Corre (1975). Silicic acid in samples collected in 1988 and in 1997 to 1998 was determined according to Atlas et al. (1971) and Gordon et al. (1993), respectively.

Chl $\boldsymbol{a}$ and phytopigments. Techniques used for chl a and phytopigments determination are summarized in Table 2. In 1979 and 1986, chl a was extracted by grinding the filters in $90 \%$ acetone, and measured by spectrophotometric techniques. Chl a concentration was calculated using the SCOR-UNESCO (1966) equation in 1979 and the Lorenzen (1967) equations in 1986. In 1988, 1997 and 1998, frozen filters were extracted in $100 \%$ methanol using sonication. Chl a and other phytoplankton pigments were separated and quantified by reverse phase HPLC on a C18 column. Divinyl chl a was not resolved from chl $a$ and the sum of both chlorophylls is referred to as chl a. The procedure of Mantoura \& Llewellyn (1983) was followed in 1988. In
1997 and 1998, pigments were analyzed according to the method proposed by Williams \& Claustre (1991), which allows better pigment separation. Chl a is used as the index of phytoplankton biomass, and carotenoid pigments provide class-specific differentiation, allowing the recognition of the major taxonomic groups of phytoplankton (Latasa \& Bidigare 1998). Fucoxanthin and the sum of $19^{\prime}$-hexanoyloxyfucoxanthin $\left(19^{\prime}\right.$-HF) and $19^{\prime}$-butanoyloxyfucoxanthin $\left(19^{\prime}-\mathrm{BF}\right)$ are used as chemotaxonomic tools to identify diatoms (e.g. Jeffrey 1980, Claustre et al. 1994) and chlorophyll c containing nanoflagellates (e.g. Claustre et al. 1994, Vidussi et al. 2000), respectively.

Changes in the techniques for chl a determination are the result of the tremendous technical advances in analytical procedures that occurred over the last 3 decades. Keeping in mind the following points for the interpretation of data, we chose to work with the original values, without any correction:

Filters: The use of GF/C filters during the first 2 timeseries may have resulted in an underestimation of chl a concentration. However, both GF/C and GF/F filters retain a higher proportion of small particles than could be expected from their nominal pore sizes. In a study carried out in coastal and oligotrophic open areas of the North Pacific, Venrick et al. (1987) found that GF/C filters passed, on average, from 4.4 to $8.9 \%$ of total chl a retained by $0.45 \mu \mathrm{m}$ Millipore filters. Similarly in the northwestern Mediterranean, parallel measurements using GF/C and $0.4 \mu \mathrm{m}$ Nucleopore filters did not show significant differences (Estrada et al. 1993).

Extraction techniques and solvents: Comparison between grinding and sonication is difficult because of the different designs and geometry of the extractors (Jeffrey et al. 1997). Acetone is used to extract pigments for spectrophotometric analysis, since equations for chl a were developed for this solvent (Jeffrey \& Humphrey 1975). For HPLC analysis, Jeffrey et al. (1997) recommend sonication of routine field samples after extraction in methanol, since the reliability of extraction with methanol is excellent, as is the compatibility with HPLC solvents.

Comparison of chl a calculated with the SCORUNESCO (1966) and Lorenzen (1967) equations: Chl a calculated with the SCOR-UNESCO (1966) equations

Table 2. Methods used for chl $a$ and carotenoids determination during the 5 time-series

\begin{tabular}{|lccccl|}
\hline Year & Filters & Volume filtered (l) & Method & Extraction solvent (\%) & Reference \\
\hline 1979 & Whatman GF/C & 5 & Spectrophotometric & 90 acetone & SCOR-UNESCO (1966) \\
1986 & Whatman GF/C & 2 & Spectrophotometric & 90 acetone & Lorenzen (1967) \\
1988 & Whatman GF/F & 2 & HPLC & 100 methanol & Mantoura \& Llewellyn (1983) \\
1997 & Whatman GF/F & 2 & HPLC & 100 methanol & Williams \& Claustre (1991) \\
1998 & Whatman GF/F & 2 & HPLC & 100 methanol & Williams \& Claustre (1991) \\
\hline
\end{tabular}


estimates chl a with a $2 \%$ error when chl a is the only chlorophyll pigment present (Lorenzen \& Jeffrey 1980). When the presence of chlorophyll degradation products from senescent cells and fecal pellets is expected, acidification of the extract (e.g. Lorenzen 1967) allows to differentiate between [chl $a+$ chlorophyllide] and phaeophorbide. However, chlorophyllide is measured as chl $a$, and the error is directly proportional to its abundance relative to chl a (Lorenzen \& Jeffrey 1980). For the Ligurian Sea, a comparison between chl a concentrations obtained with the SCOR-UNESCO (1966) and Lorenzen (1967) equations is reported in Goffart (1992). On the basis of 500 samples collected in the upper $100 \mathrm{~m}$, the relationship computed using a model II linear regression following the standard major axis method (Legendre \& Legendre 1998) is: Chl $a_{\text {Lorenzen } 1967}=0.86 \times \mathrm{chl} a$ SCOR-UNESCO $1966-0.01$.

In the Bay of Calvi, the slope of the correlation line is slightly higher and the regression obtained from the comparative analysis of 62 samples collected at $1 \mathrm{~m}$ depth is: Chl $a_{\text {Lorenzen } 1967}=0.91 \times \mathrm{chl} a_{\text {SCOR-UNESCO } 1966}-0.01$.

Comparison of chl a calculated with the Lorenzen (1967) equation and determined by HPLC: In the Bay of Calvi, very close results were obtained for $\mathrm{chl}$ a from Lorenzen (1967) as compared with the HPLC technique (Goffart 1992, A.G. unpubl. data). This is because chlorophyllide is absent in the oligotrophic waters of the Bay of Calvi and in the euphotic zone along the western Corsican coast. On the basis of 141 samples collected in the upper $100 \mathrm{~m}$ of these 2 areas, the relationship computed using a Model II linear regression following the standard major axis method (Legendre \& Legendre 1998) is: Chl $a_{\text {HPLC (Mantoura \& Llewellyn 1983) }}=$ $0.97 \times \mathrm{chl} a$ Lorenzen $1967-0.01$. This relationship does not apply to offshore waters associated with the LiguroProvençal frontal zone, where enhanced autotrophic biomass and variable chlorophyllide concentrations are observed.

Water temperature. In 1979, 26 temperature measurements were done at $2 \mathrm{~m}$ depth over the sampling period. From 1981 to 1998, water temperature at $2 \mathrm{~m}$ was measured daily at 09:00 h (local time) between 1 January and 30 April. An underwater thermometer (precision: $\pm 0.1^{\circ} \mathrm{C}$ ) was used until 1996 and replaced by an Aanderaa temperature sensor 3444 (precision: $\pm 0.02^{\circ} \mathrm{C}$ ) in 1997 and 1998 .

Meteorological variables. Meteorological data recorded between 1979 and 1998 were provided by Météo-France. Bright sunshine, expressed in h, was recorded at the Calvi, Ajaccio and Figari airports (Fig. 1). Values used in this study are the total numbers of sunny hour $\mathrm{mo}^{-1}$. Wind speed $\left(\mathrm{m} \mathrm{s}^{-1}\right)$ was recorded every third $\mathrm{h}$ at the Calvi and Figari airports (Fig. 1). Mean daily and monthly wind speeds were calculated from these data. Wind data at the Calvi airport are not available in 1980 and 1981. Wind data from Ajaccio are not considered here because the wind field there is not representative of dominant winds. All rainwater events recorded at Calvi between the 1 January and 30 April of each year were added to obtain the total amount of rainfall (mm).

DYFAMED data. The values of some variables determined in the Bay of Calvi during the 5 time-series were compared with salinity, nitrate, silicic acid and fucoxanthin obtained between 1991 and 1993 at the JGOFS-France time-series station DYFAMED. That station is located in the central Ligurian Sea $\left(43^{\circ} 25^{\prime} \mathrm{N}\right.$, $7^{\circ} 52^{\prime}$ E, Fig. 1), about 60 miles (96.6 km) NW of Calvi. The DYFAMED data base, coordinated by Dr. J. C. Marty, is available at: www.obs-vlfr.fr/jgofs2/sodyf/ home.htm and on a CD-ROM (Marty 2000).
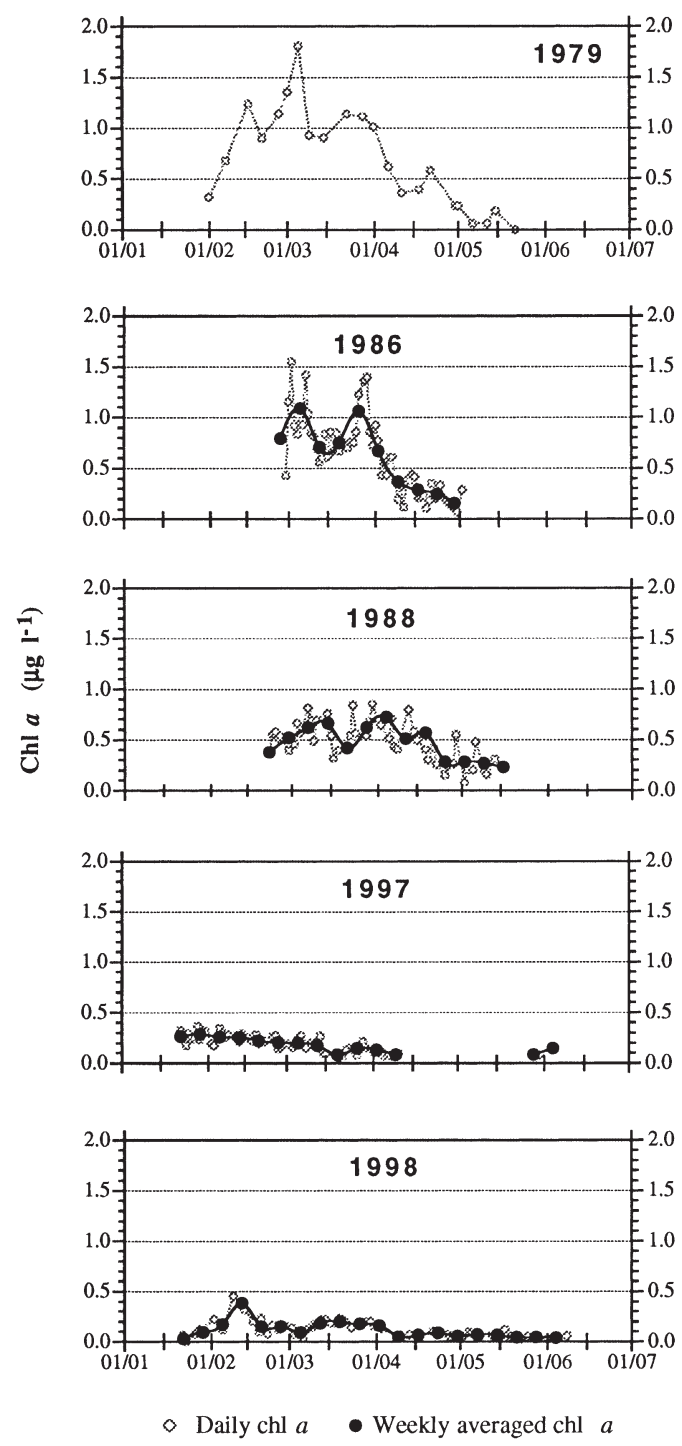

Fig. 2. Temporal changes in chl a concentration at $1 \mathrm{~m}$ in the Bay of Calvi during the 5 time-series. Data from 1979 are redrawn from Hecq et al. (1981) 

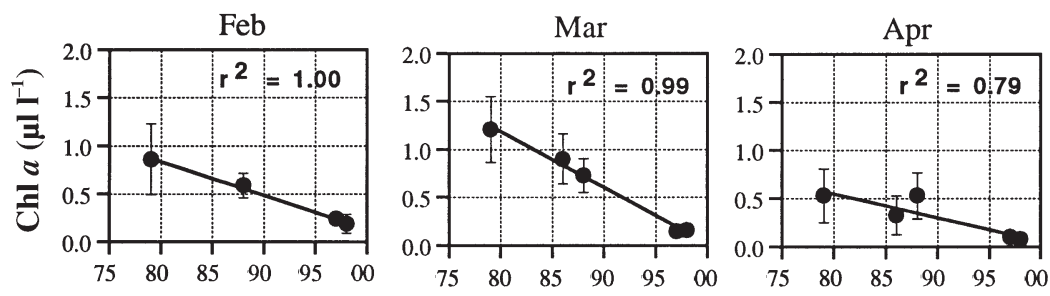

the winter-spring maxima were observed very early in the season, at the end of January in 1997 and by mid-February in 1998, i.e. 3 to $5 \mathrm{wk}$ earlier than the chl a maxima in 1979 and 1986.

Plots of monthly averaged chl a against year stress the progressive diminution of phytoplankton biomass during the winter-spring period during the last 2 decades (Fig. 3). Over the 1979 to 1998 period, there was a linear, highly significant decrease in chl a con-

\section{RESULTS}

\section{Phytoplankton biomass}

Seasonal changes in chl a concentration at $1 \mathrm{~m}$ during the 5 time-series are shown in Fig. 2. In 1979, chl a concentrations started to increase at the beginning of February, and reached a maximum value of $1.81 \mu \mathrm{g} \mathrm{chl} \mathrm{a} \mathrm{l}^{-1}$ in early March. There were 2 smaller peaks later, before the final decay of the bloom at the beginning of May. In 1986, temporal changes in chl a were similar to those of 1979 in terms of the timing of both bloom initiation and decay. There were 2 successive pulses of chl a concentrations, but the maximum value $\left(1.55 \mu \mathrm{g} \mathrm{chl} \mathrm{a} \mathrm{l}^{-1}\right)$ was slightly lower than in 1979. Surprisingly, in 1988, there was no bloom during the sampling period, as chl a con-

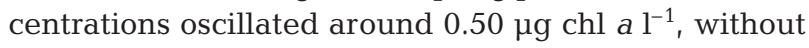
peaking, from late February to mid-April. In 1997 and 1998, the sampling began much earlier in the season than in previous years, in order to study the processes associated with the triggering of the winter-spring bloom. Nevertheless, no bloom was detected in either year, and chl a concentrations remained very low during the whole studied periods. The highest values were only $0.37 \mu \mathrm{g}$ chl a $\mathrm{l}^{-1}$ in 1997 and $0.45 \mu \mathrm{g} \mathrm{chl} \mathrm{a} \mathrm{l}^{-1}$ in 1998. Moreover, centrations during February $\left(\mathrm{r}^{2}=1.00\right)$, March $\left(\mathrm{r}^{2}=\right.$ 0.99) and April $\left(r^{2}=0.79\right)$, i.e. the monthly averaged values decreased by about $80 \%$ in the 3 mo.

\section{Water temperature, meteorological variables and environmental factors}

Figs. 4, 5 \& 6 illustrate the 20 yr variations of environmental variables that may have driven the spectacular changes observed in the development of the winter-spring phytoplankton bloom. These variables are water temperature, bright sunshine and wind speed, for which data are available since 1979. Because the variables control the supply of nutrients from deep waters before and during the phytoplankton bloom, we examine the data from January to April. The upper panels show values for the $5 \mathrm{yr}$ when chl a was sampled, and the lower panels display the full 1979 to 1998 data set.

There was a continuous, significant linear increase of water temperature in February, March and April over the 1979 to 1998 period (Fig. 4). In addition, there was a warming trend in January, despite strong interannual variability. There were concomitant, significant linear in-
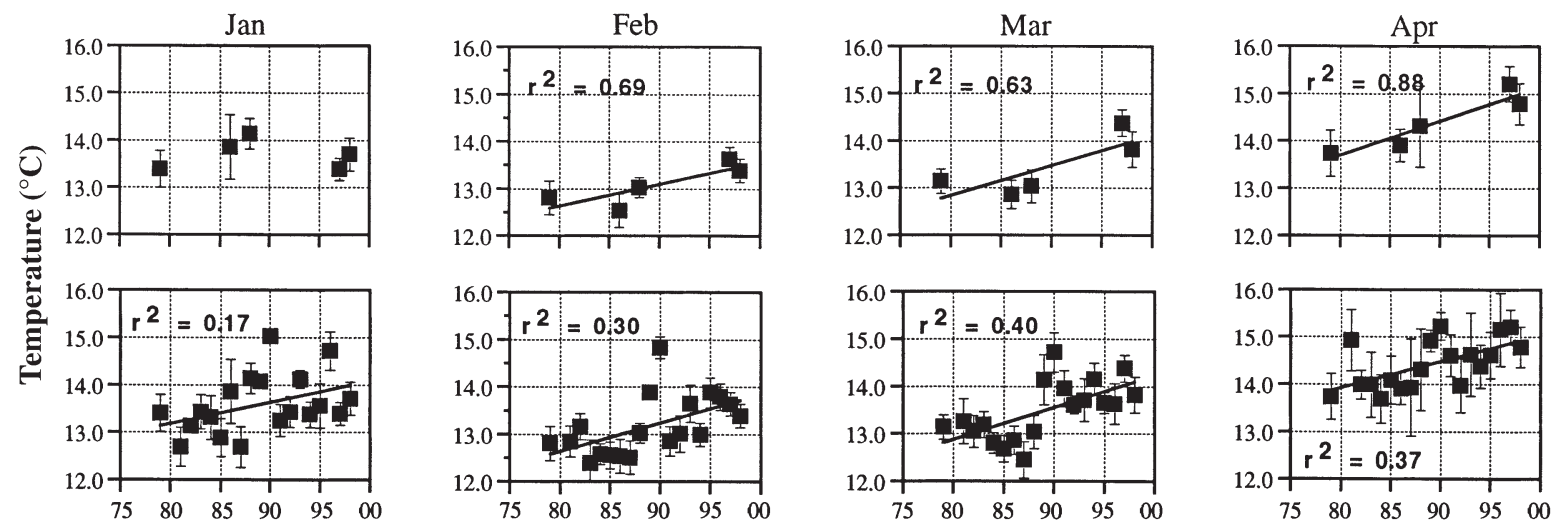

Fig. 4. Changes in monthly averaged subsurface temperature with year in the Bay of Calvi during the 5 time-series when the winter-spring phytoplankton bloom was studied (upper panels), and for the full 1979 to 1998 period (lower panels). Error bars and linear regression lines are shown; $\mathrm{r}^{2}$ : coefficient of determination 

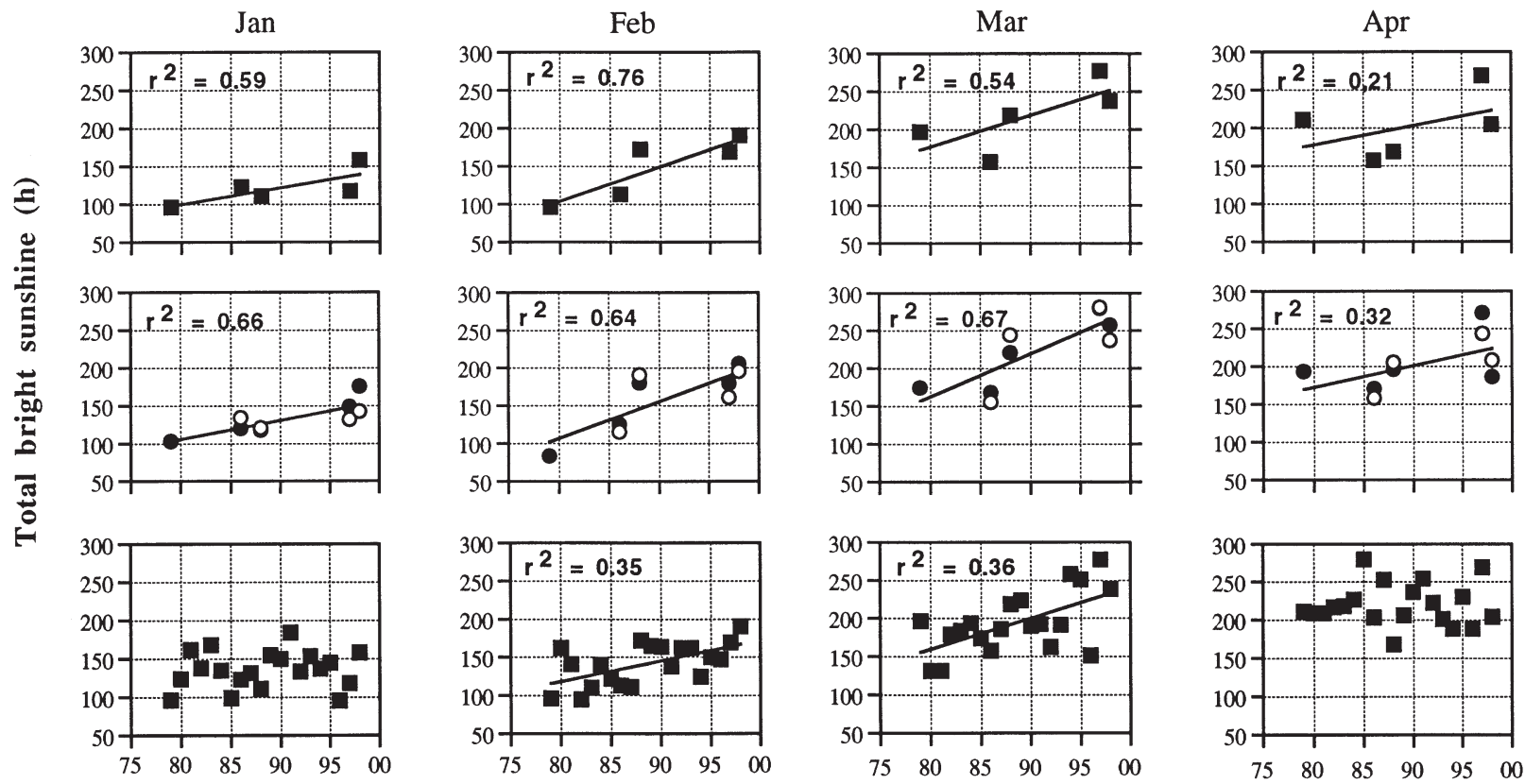

\section{Calvi $\quad$ Ajaccio $\circ$ Figari}

Fig. 5. Changes in monthly total bright sunshine against time, at Calvi (upper panels), and Ajaccio and Figari (intermediate panels) Airports, during the 5 time-series when the winter-spring phytoplankton bloom was studied, and for the full 1979 to 1998 period at Calvi Airport (lower panels). Error bars and linear regression lines are shown; $\mathrm{r}^{2}$ : coefficient of determination. Figari

Airport opened in 1980
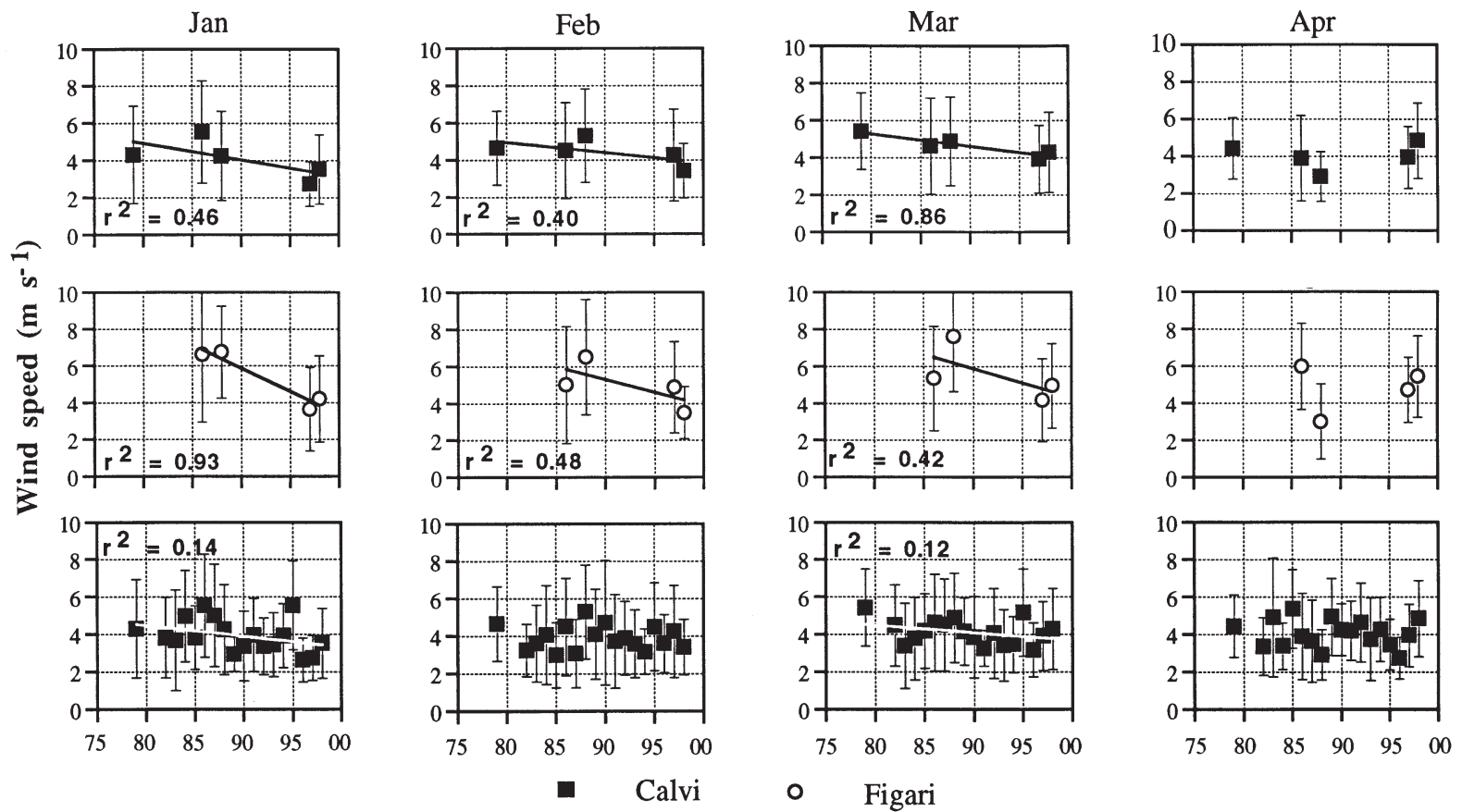

Fig. 6. Changes in monthly wind speed against time at Calvi (upper panels) and Figari (intermediate panels) Airports during the 5 time-series when the winter-spring phytoplankton bloom was studied, and for the full 1979 to 1998 period at Calvi Airport (lower panels). Error bars and linear regression lines are shown; $\mathrm{r}^{2}$ : coefficient of determination. Figari Airport opened in 1980. Wind data at Calvi Airport are not available for 1980 and 1981 

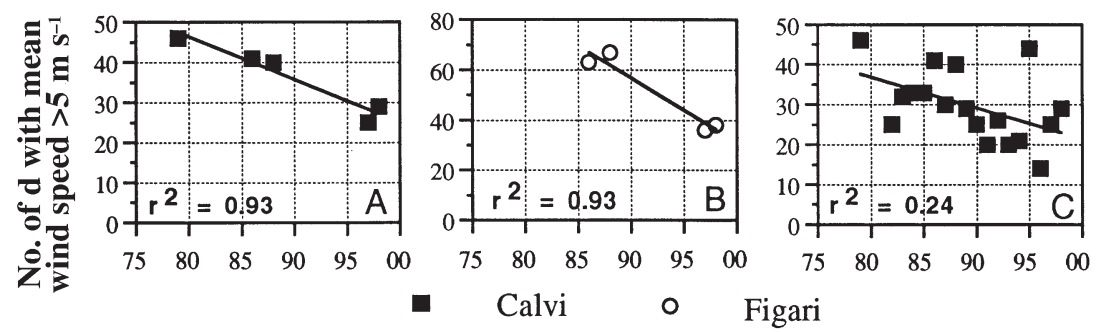

Fig. 7. Changes in the numbers of days with mean wind speed $>5 \mathrm{~m} \mathrm{~s}^{-1}$ between 1 January and 30 April against time at (A) Calvi and (B) Figari Airports during the 5 time-series when the winter-spring phytoplankton bloom was studied, and (C) for the full 1979 to 1998 period at Calvi Airport. Error bars and linear regression lines are shown; $r^{2}$ : coefficient of determination. Figari Airport opened in 1980. Wind data at Calvi Airport are not available for 1980 and 1981 creases in monthly total bright sunshine at Calvi, Ajaccio and Figari (Fig. 5). The most spectacular change occurred in February, when the number of sunny hours doubled between 1979 and 1998. It must be noted, however, that the changes in January and April are not significant when considering the full 1979 to 1998 data set (lower panels). Contrary to temperature and sunshine, the monthly wind speed tended to decrease in January, February and March at both Calvi and Figari (Fig. 6), but the change in February is not significant when considering the full 1979 to 1998 data set (lower panels). In addition, the number of days with strong winds (mean speed $>5 \mathrm{~m} \mathrm{~s}^{-1}$ ) between 1 January and 30 April decreased linearly at both Calvi and Figari $\left(\mathrm{r}^{2}=0.93\right)$ for the $5 \mathrm{yr}$ when chl a was sampled (Fig. 7). The complete data set at Calvi shows higher interannual variability (Fig. 7) but confirms the change over the 1979 to 1998 period.

In summary, the physical forcing factors show clear and consistent trends through the year when chl a was sampled. Even if the full 1979 to 1998 data set is much noisier, Figs. 4 to 7 show that between 1979 and 1998, (1) water temperature increased in January, February, March and April; (2) monthly bright sunshine increased in February and March; and (3) the monthly average wind speed tended to weaken slightly in January and March. Moreover, the frequency of wind bursts decreased during the winter-spring period, i.e. between January and April.

Other environmental factors to be considered include possible nutrient input from rainwater, water salinity, and nutrients. Concerning rainwater, data from the Calvi airport show decreasing precipitations from January through April since 1979 (Fig. 8). Salinity was not monitored systematically during the phytoplankton time-series, because it is generally accepted that surface waters near Corsica have a rather constant salinity $\geq 38.0$ (Hopkins 1985, Goffart et al. 1995; up to 38.3 in the north of the western Mediterranean, Millot

Fig. 9. Changes in average salinity at $10 \mathrm{~m}$ between the 1 January and 30 April against time in the Bay of Calvi. The average values were calculated from data acquired during 1 to 48 hydrological casts. Error bars and linear regression line are shown; $\mathrm{r}^{2}$ : coefficient of determination
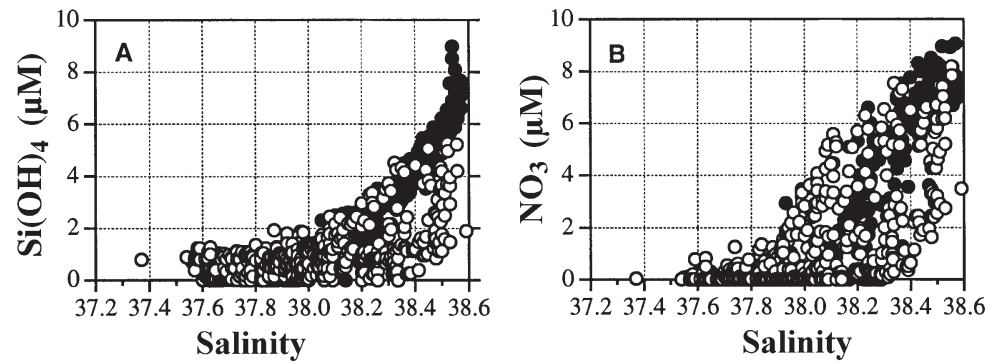

Fig. 10. Relationships between salinity and nutrient concentrations in the Liguro-Provençal basin. (A) Silicic acid (o: 915 data points; 248 data points). (B) Nitrate (०: 948 data points; $\bullet 246$ data points). 0 are from the Bay of Calvi and from stations located along the CalviNice axis between the Corsican coast and 30 miles $(48.3 \mathrm{~km})$ offshore; data collected between 1988 and 1998, at depths ranging from 0 to $200 \mathrm{~m}$. are from the DYFAMED station (Marty 1999, DYFAMED Observation Service); data collected between 1991 and 1993, at depths ranging from 0 to $500 \mathrm{~m}$ 
1999). Nevertheless, the scattered winter-spring data available in the Bay of Calvi show a generally decreasing trend in subsurface salinity $(10 \mathrm{~m})$ over the studied period (Fig. 9), i.e. subsurface salinity observed at the end of winter at the beginning of the 1980s was about 38.2, which is in good agreement with values found in the literature (e.g. Nyffeler \& Prieur 1972, Hopkins 1985), and winter-spring salinity after
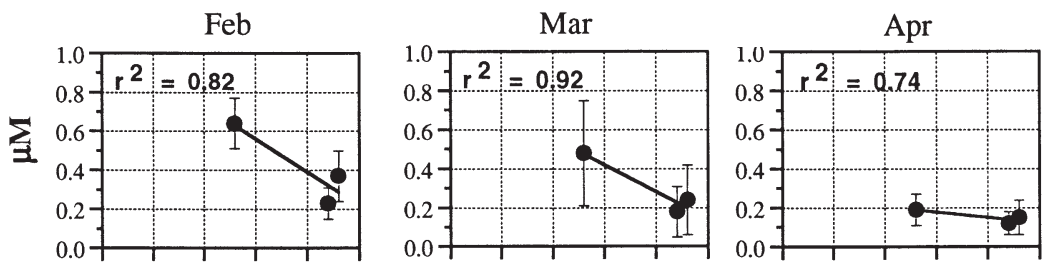

Fig. 11. Changes in monthly averaged nitrate at $1 \mathrm{~m}$ against time in the Bay of Calvi during the last 3 time-series when the winter-spring phytoplankton blooms were studied. Error bars and linear regression lines are shown; $r^{2}$ : coefficient of determination

1990 was around 37.8. Relationships between salinity and nutrient concentrations, based on a robust data set, show that, in the area of Calvi and the central Ligurian Sea, silicic acid and nitrate concentrations increased from undetectable or low levels to maximum values with increasing salinity (Fig. 10). In addition, maximum daily silicic acid and nitrate concentrations during the last 3 timeseries $(1988,1997$ and 1998) were both $<1.2 \mu \mathrm{M}$, and there was a significant decrease in nitrate between 1988 and 1998 (Fig. 11), while silicic acid did not show any trend. Available information on the vertical structure of the water column for the last 2 time-series clearly shows nutrient depletion down to 60 and $100 \mathrm{~m}$ in 1997 and 1998, respectively (Fig. 12).

\section{Diatom contribution to chl a}

Because of the absence of phytoplankton counts, we assessed the contribution of diatoms to chl a in 1988, 1997 and 1998 from fucoxanthin, which is the diagnostic pigment for diatoms. The chl a concentration associated with diatoms was taken as equal to the product of fucoxanthin by 1.25, according to Barlow et al. (1993) and Claustre et al. (1994). In the Bay of Calvi, maximum daily diatom contribution reached 20, 29 and $26 \%$ of the total chl a in 1988, 1997 and 1998, respectively, the average diatom contribution during the winter-spring period being 9, 17 and $14 \%$, respectively

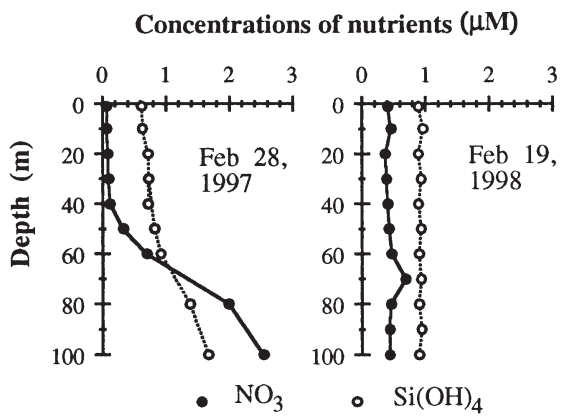

Fig. 12. Vertical distributions of $\mathrm{NO}_{3}$ and $\mathrm{Si}(\mathrm{OH})_{4}$ in the outer part of the Bay of Calvi in February 1997 and 1998
(Fig. 13, upper panels). In contrast to diatoms, nanoflagellates containing $19^{\prime}-\mathrm{HF}$ and $19^{\prime}$-BF were the largest contributors to chl a in 1988, 1997 and 1998. The major changes in algal biomass during the last decade were due to changes in nanoflagellate abundance, as indicated by the strong positive linear relationship between chl $a$ and the sum of $19^{\prime}$-HF and 19' BF (Fig. 14). The bottom panel of Fig. 13 shows the general relationship between silicic acid concentration and diatom contribution to total chl $a$ in the central Ligurian Sea (DYFAMED long-term station): when silicic acid was low $(<1 \mu \mathrm{M})$, the contribution of diatoms did not exceed 20 to $30 \%$, as in the Bay of Calvi after 1988, but in Si-rich waters $(>1 \mu \mathrm{M})$ there was a strong positive relationship between the 2 variables. Hence, there is a sharp increase in the contribution of diatoms to total chl a from oligotrophic to mesotrophic conditions. By combining Figs. 10 \& 13, we associated to the salinities observed in the Bay of Calvi between 1979 and
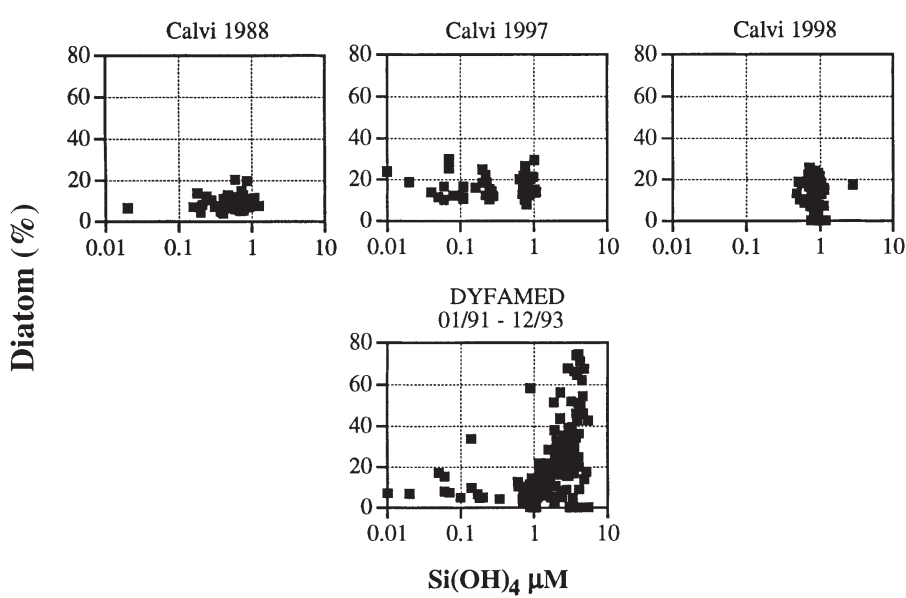

Fig. 13. Relationship between silicic acid concentration and percent diatom contribution to $\mathrm{chl}$ a for the time-series in the Bay of Calvi in 1988, 1997 and 1998, and data from the DYFAMED station (central zone of the Ligurian Sea), obtained in the upper $250 \mathrm{~m}$ between January 1991 and December 1993 (Marty 2002, DYFAMED Observation Service). Divinyl chl a concentrations are included in chl a concentrations 


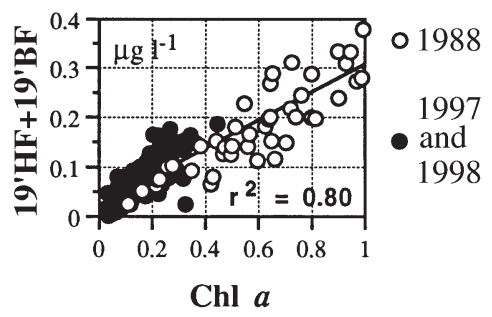

Fig. 14. Relationship between chl $a$ and $19^{\prime}-\mathrm{HF}+19^{\prime}-\mathrm{BF}$ concentrations $\left(\mu \mathrm{g} \mathrm{I}^{-1}\right)$ in the Bay of Calvi during the last 3 time-series when the winter-spring phytoplankton blooms were studied. Regression line is shown; $\mathrm{r}^{2}$ : coefficient of determination

1998 maximum concentrations of nitrate and silicic acid, and used the latter to derive a maximum contribution of diatoms to total chl a (Table 3).

\section{DISCUSSION}

\section{Nutrient input to the surface layer}

Major changes to hydrodynamic conditions in the Bay of Calvi since 1979 include warmer water and lower wind stress (Figs. 4, 6 \& 7). The first may be explained, at least partly, by the longer periods of bright sunshine (Fig. 5). Assuming that changes in water temperature and meteorological conditions were large enough to affect the vertical stability of the water column during the winter-spring period, this could have caused a significant reduction in vertical mixing and, consequently, in the upward transfer to surface waters of nutrients from depth. Because vertical mixing is the major mechanism of nutrient enrichment in the Bay of Calvi, we hypothesize that reduced nutrient replenishment of the surface layer before the onset of the phytoplankton bloom and during the productive season contributed significantly to the drastic reduction of phytoplankton biomass observed over the last 2 decades (Figs. $2 \& 3$ ).

Although the intensity of vertical mixing in the Calvi area is largely unknown, the existing salinity and nutrient data can be used to assess the variability in nutrient replenishment of the upper mixed layer over the 1979 to 1998 period. In the Ligurian Sea and along the western Corsican coast, the surface (0 to $150 \mathrm{~m}$ ) and intermediate (150 to $700 \mathrm{~m}$ ) layers are characterized by increasing salinity with depth, the maximum value generally occurring between 300 and $400 \mathrm{~m}$ (e.g. Coste et al. 1972, Goffart 1992, Bethoux et al. 1998, Millot 1999). If vertical mixing in the Bay of Calvi decreased in relation to the observed changes in meteorological conditions, there should have been a re-
Table 3. Maximum nutrient concentrations and diatom contribution as a function of salinity in the Ligurian Sea and in the Bay of Calvi

\begin{tabular}{|lccc|}
\hline Salinity & $\begin{array}{c}\text { Max. } \mathrm{NO}_{3} \\
\text { conc. }(\mu \mathrm{M})\end{array}$ & $\begin{array}{c}\text { Max. } \mathrm{Si}(\mathrm{OH})_{4} \\
\text { conc. }(\mu \mathrm{M})\end{array}$ & $\begin{array}{c}\text { Max. diatom } \\
\text { contribution } \\
(\% \text { of total chl } a)\end{array}$ \\
\hline 37.8 & 1.4 & 1.4 & 25 \\
38.0 & 3.5 & 2.0 & $35-40$ \\
38.2 & 6.3 & 3.0 & 60 \\
38.4 & 8.2 & 5.0 & $>60$ \\
\hline
\end{tabular}

duction in the input of highly saline water from depth to the surface layer, hence decreased surface salinity. The observed overall decrease of salinity at $10 \mathrm{~m}$ depth between 1979 and 1998 (Fig. 9) is consistent with our hypothesis of reduced nutrient replenishment of the surface waters over the last 2 decades, caused by a progressive reduction of vertical mixing of the water column.

In the region of Calvi and in the central Ligurian Sea, silicic acid and nitrate concentrations increased with salinity (Fig. 10). High values of the 2 nutrients are normally found at depths where there is no uptake by photosynthetic organisms or in recently upwelled waters. Hence, the maximum concentrations of silicic acid and nitrate in Ligurian Sea waters with salinity of 38.2 are 3.0 and $6.3 \mu \mathrm{M}$, respectively, whereas in waters with a salinity of 37.8 , the maximum values are only $1.4 \mu \mathrm{M}$ for the 2 nutrients. Thus, the salinity decrease of ca. 0.4 that occurred in the Bay of Calvi between 1979 and 1998 could have reduced the stock of nutrients in surface waters at the end of winter to $<1 \mu \mathrm{M}$. This is consistent with our nutrient limitation hypothesis. The low values of both silicic acid and nitrate in 1988, 1997 and 1998 [monthly averaged $\mathrm{NO}_{3}$ and $\left.\mathrm{Si}(\mathrm{OH})_{4}<1 \mu \mathrm{M}\right]$ confirm the oligotrophic character of the Bay of Calvi during the last decade, even during the winter-spring period. In addition, the significant decrease in nitrate since 1988 (Fig. 11) likely reflects a reduction in winter mixing, prior to the usual period of phytoplankton growth. By mid- (1998) or late (1997) February, the 2 nutrients were depleted at depth (Fig. 12).

Other nutrient sources than vertical mixing, such as land, river runoff, urban sewage and rainwater, have been identified as influencing phytoplankton new production in coastal areas of the western Mediterranean (Estrada 1996, Duarte et al. 1999). In the Bay of Calvi, however, external nutrient sources are limited and do not release the oligotrophy of surface waters during the winter-spring period. Because of the absence of agricultural and industrial activities, and the small winter population (ca. 2000 residents), nutrient enrichment 
through local human activities is negligible between October and May. Local runoff from the Figarella River is small and irregular, in relation with the stormy rainfall regime. Nutrient inputs from rainwater are episodic and characterized by high temporal variability in total concentration [from 1 to $>100 \mu \mathrm{mol} \mathrm{NO}_{3} \mathrm{l}^{-1}$, and 0 to $17 \mu \mathrm{mol}$ $\mathrm{Si}(\mathrm{OH})_{4} 1^{-1}$; A.G. \& J.-H.H. unpubl. data]. Given that the January to April precipitations continuously decreased since 1979 (Fig. 8), the possible fertilizing role of rainfall nutrient input should have decreased over the 1979 to 1998 period. This contributes to reduce still further the amount of nutrients available in the surface layer, already affected by the reduction in vertical mixing.

It follows from the above that, despite the uncertainties related to the incomplete data set: (1) the 1979 and 1986 phytoplankton peaks took place in relatively high-nutrient waters, after the winter nutrient replenishment of surface waters; (2) from 1988, the progressively increasing water temperature and altered meteorological conditions caused a reduction of nutrient replenishment, and thus phytoplankton biomass; and (3) the main factor driving nutrient replenishment until 1986 was the winter upward mixing of nutrient-rich deep waters, and the progressive reduction of mixing from 1988 was the main cause for the nutrient limitation of surface waters. These conclusions all agree with our above hypothesis.

\section{Taxonomic composition of the phytoplankton bloom}

Nutrient limitation can deeply influence the taxonomic composition of the phytoplankton community. Diatoms contribute up to $76 \%$ of the chl a biomass in Mediterranean productive areas (Claustre et al. 1994). We focus our analysis on these organisms, because they are very sensitive to nutrient limitation (Officer \& Rythere 1980, Brzezinski et al. 1997) and the very low silicic acid concentrations in the Bay of Calvi in 1988, 1997 and 1998 could have caused Si limitation of diatom production. The low contribution of diatoms to total chl a during the last 3 time-series (Fig. 13, upper panels) contrasts with the high to moderate values reported for blooms (up to $70 \%$, Bustillos-Guzmán et al. 1995) or late blooms (around 30\%, Vidussi et al. 2000) in the western Mediterranean. Values in the Bay of Calvi are, however, comparable even if slightly lower to those reported for another coastal site of the Ligurian Sea (Stn B in the Bay of Villefranche-sur-Mer, France, Bustillos-Guzmán et al. 1995, Fig. 1) in March to April 1992 and January to April 1993. It is important to note that these authors report the lack of the classical spring diatom bloom as one of the main findings of their investigation. As mentioned above, no remarkable chl $a$ increase was recorded during the winter-spring period and phytoplankton was dominated by nanoflagellates containing 19'-BF and 19'-HF.

The above discussion leads to the following scenario. Table 3 and Fig. 13 show that, under favorable irradiance conditions, the development of a phytoplankton bloom in waters mixed upwards from depth strongly depends on its silicic acid content, which is closely related to salinity in the Ligurian Sea (Fig. 10). In the Bay of Calvi, diatoms were probably the major constituents of phytoplankton peaks in the high salinity surface waters until 1986. Between 1986 and 1988, the changing environmental conditions likely caused a reduction in diatom abundance through Si limitation, which resulted in lower phytoplankton biomass. Hence, the disappearance of the diatom-dominated pulses between 1986 and 1988 was accompanied by a shift toward non-siliceous phytoplankton. In 1988, 1997 and 1998, decreasing nitrate availability (Fig. 11) led to nitrate limitation, thus explaining the progressive reduction in non-siliceous phytoplankton biomass.

\section{Other examples of ecosystem changes in the Bay of Calvi}

Simultaneously to the reduction of phytoplankton biomass during the winter-spring period, the surface covered by Cystoseira balearica in the Bay of Calvi and its standing crop have decreased since 1980 (Hoffmann et al. 1988). That benthic species is a major component of algal communities on rocky substrates in the bay. From 1987 onwards, the decline was so pronounced that growth measurements became meaningless (Hoffmann et al. 1992, V. Demoulin pers. comm.). Since the main growing season of $C$. balearica is the winter-spring period, during which ca. $70 \%$ of the total yearly biomass is produced (Hoffmann et al. 1992), the reduction in nutrient replenishment of surface waters could explain the drastic reduction of this alga. Moreover, intense and unusual flowerings of the Posidonia oceanica seagrass meadows, which occupy the upper $40 \mathrm{~m}$ in sandy areas of the bay, were observed in 1994 and 1997 (S. Gobert unpubl.). This may have been caused, among other factors, by the significant longterm increase in water temperature, which is known to have direct effects on seagrass flowering and seed germination (see the review of Short \& Neckles 1999). Therefore, the changing environmental conditions in the Bay of Calvi during the winter-spring period seem to have affected all primary producers, including benthic communities. The general trend of decreasing planktonic and benthic primary production must have a profound influence on the functioning of the whole food web and could lead to a major shift in the overall ecosystem. 
Additional evidence of ecosystem change is provided by the recent occurrence in the Bay of Calvi of the fish Thalassoma pavo, which was previously observed in the warm eastern Mediterranean basin only. At the beginning of the 1980s, T. pavo was absent in the Bay of Calvi. At the end of the 1990s, both adults and juveniles were abundant in the upper $15 \mathrm{~m}$ (A.G. pers. obs.), probably related to the long-term increase of water temperature.

\section{Are there similar changes in the Ligurian Sea?}

The last objective of this study is to determine if the major changes observed in the Bay of Calvi occurred at a local scale only, or are consistent with long-term trends observed in other areas of the Ligurian Sea. The 3 main zones recognized in the Ligurian Sea at the basin scale, i.e. the coastal-peripheral zone, the permanent frontal zone and the central zone (Fig. 1), differ in their physical forcing, nutrient concentrations, plankton composition, and primary and secondary production (Boucher et al. 1987, Goffart 1992, Goffart et al. 1995, Pinca \& Dallot 1995). Consequently, the different zones must be considered separately.

\section{Central zone}

In the central zone, wind mixing is more effective in supplying nutrients to the surface than in the coastal area, in relation with the shoaling of the nutricline which is observed from the coast to the central part of the basin. Therefore, there are substantial concentrations of nutrients in the euphotic zone, and a moderate winter-spring bloom develops each year in the nutrient-rich waters of the central zone (e.g. Goffart 1992, DYFAMED Observation Service). Chl a concentrations reported at the end of the 1960s (Jacques et al. 1973) and in the 1980s (Pinca $\&$ Dallot 1995) are within the range of those observed in 1995 (Vidussi et al. 2000). Moreover, the usual increase in diatom biomass as a consequence of vertical nutrient transport consecutive to a wind event was still observed in 1995 (Vidussi et al. 2000). The difference in phytoplankton abundance between the central and coastal zones was observed in 1997 and 1998 as before during the winter-spring period, with maximum chl $a$ in the upper $10 \mathrm{~m}$ reaching $1 \mu \mathrm{g} \mathrm{chl} \mathrm{a} \mathrm{l}^{-1}$ in the central zone (DYFAMED Observation Service), i.e. 2 to 3 times higher than in the Bay of Calvi. However, there has been an increasing contribution of small cells to the total phytoplankton biomass at station DYFAMED in the last decade (Marty et al. 2002), which could be a first indication of changing phytoplankton dynamics in the central part of the Ligurian Sea.

\section{Frontal zone}

Ten yr of investigations on phytoplankton ecology performed in the Liguro-Provençal frontal area (Corsican sector) between 1982 and 1991 have shown that the role of the front in enhancing phytoplankton biomass and primary production is important throughout the year, but is much more effective from March to May (Goffart 1992). The data set shows that there may be strong interannual variability in phytoplankton biomass during the winter-spring period (magnitude of fluctuation: from 1 to 4 ), but no temporal trend was detected during that period.

\section{Coastal-peripheral zone}

Although many ecological studies were carried out in the coastal areas of the Ligurian Sea, there is paucity of multiyear surveys of phytoplankton in relation with long-term records of environmental variables. Our approach was therefore to compare the changes observed in the Bay of Calvi with the patchy information on long-term changes in the euphotic zone available for other coastal areas of the northwestern Mediterranean.

\section{Water temperature}

Along the western Corsican coast, Calvi is the only station at which there is a long-term series of sea subsurface water temperature. However, at Scandola, which is a marine reserve located $40 \mathrm{~km}$ south of Calvi (Fig. 1), thermophilic algae, echinoderms and fishes have become newly established or more abundant during the last several years, while less thermophilic species have regressed strongly (Francour et al. 1994). As in the Bay of Calvi, the abundance of Thalassoma pavo, a thermophilic fish, has increased strongly during the last decade. According to Francour et al. (1994), the arrival of T. pavo at Scandola dates back to 1988. Since then, its concentration has increased by a factor of 10 and juveniles have been observed since March 1991. Another spectacular increase was detected for the thermophilic Echinoidea Arbacia lixula, of which the abundance has multiplied by more than 10 between 1983 and 1992 (Fig. 15). These changes in thermophilic ichthyofauna and benthos assemblages in the waters of Scandola reflect long-term changes in subsurface water temperature. They show that the longterm warming trend of water temperature observed in the Bay of Calvi took place at a broad spatial scale along the western Corsican coast. Moreover, the warming trend in water temperature in the Bay of 

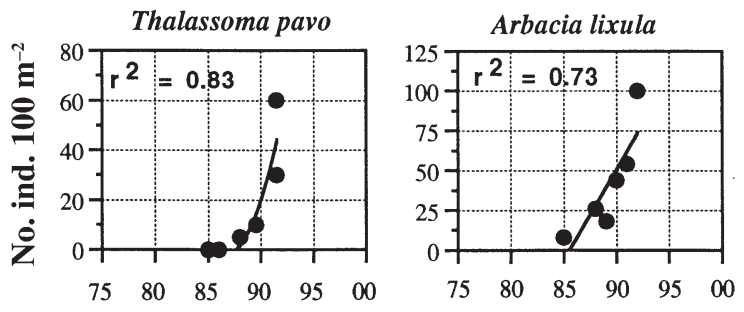

Fig. 15. Changes in the mean concentrations (number of individuals $100 \mathrm{~m}^{-2}$ ) of 2 thermophilic species in Scandola: fish Thalassoma pavo and Echinoidea Arbacia lixula. Data are from Francour et al. (1994)

Calvi is in good agreement with that observed along the Spanish Mediterranean coast, where surface water temperature increased by ca. $1^{\circ} \mathrm{C}$ between 1975 and 1994 (Marbà \& Duarte 1997). Therefore, the warming trend of coastal surface waters is likely to have affected most of or even the whole northwestern Mediterranean in the last 20 to $25 \mathrm{yr}$.

\section{Meteorological variables}

The monthly records of total bright sunshine from Ajaccio and Figari Airports, which are located along the southwestern Corsican coast (Fig. 1), both show increasing trends in solar radiation similar to those observed in Calvi during the 5 phytoplankton timeseries (Fig. 5). As a consequence, it can be assumed that the long-term increasing trend in solar radiation evidenced in Calvi for February and March over the 1979 to 1998 period was the same along the whole western Corsican coast and perhaps elsewhere in the northwestern Mediterranean. A steady increase in solar radiation has not been reported for other coastal areas of the Ligurian Sea, perhaps because monthly solar radiation analyses have not been conducted.

Similar to total bright sunshine, there were parallel changes in wind speed during the 5 phytoplankton time-series in Calvi and Figari, which is the southernmost meteorological station in Corsica (Figs. 6 \& 7). Again, it appears that climatic fluctuations observed in Calvi operated at a regional scale of $100 \mathrm{~s}$ of $\mathrm{km}$. Changes in wind conditions along the western Corsican coast between 1979 and 1998 could be a regional signature of the significant changes in winter wind fields reported for the whole Mediterranean between pre-1987 and post-1988 (Samuel et al. 1999). These authors found evidence of a weakening of Mistral forcing in the Gulf of Lions after 1987, and intensification of the winter mean wind stress (mostly in January) over the Aegean Sea and Levantine basin at the same time.
The overall decreasing trend observed in winter rainfall (January to April) in the Bay of Calvi may be a significant factor in reducing the mean freshwater input to the surface layer (Fig. 8). At the scale of the Ligurian Sea, the decrease in precipitation in Calvi is coherent with the decrease in annual rainfall observed in Monaco since 1955 (Bethoux et al. 1990, see Fig. 1). Observations along the African coast and in the Middle East (Bradley et al. 1987) are consistent with the hypothesis of a similar trend over the whole Mediterranean.

The above considerations provide further insight into the broad-scale pattern of changing environmental conditions in Mediterranean coastal areas. In particular, they show an increasing trend in subsurface water temperature and a general change in meteorological variables over the western Corsican coast since 1979. It follows that the causal relationship between modified environmental conditions and a reduction of the winter nutrient replenishment of the surface layer determined in the Bay of Calvi could be extended to the whole western Corsican coastal area. Apart from the summer influx of tourists, the oligotrophic character of the western Corsican coastal waters is further enhanced by the low runoff, small anthropogenic discharge and generally low human pressure.

\section{Nutrients and biological communities}

In Corsica, unprecedented, system-wide changes in pelagic and benthic primary producers, benthic fauna and fish assemblages occurred between 1986 and 1988, although trends in changing water temperature and meteorological conditions have been continuous since 1979. Since 1988, there has been an acceleration of biological changes, which could affect the whole marine food web.

As far as we know, long-term changes in phytoplankton communities have not been reported for other coastal Mediterranean areas. However, there is some indication of similar trends in phytoplankton composition and abundance in the Ligurian Sea between Villefranche-sur-Mer (French Riviera) and Calvi. Significant differences in phytoplankton winterspring bloom have been reported off the French coast between 1986 and 1992 to 1993. In 1986, maximum

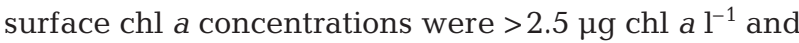
the diatom Nitzschia seriata was the dominant species (Claustre et al. 1989). This contrasts with the lower

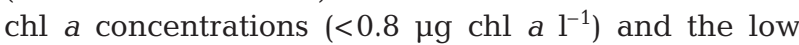
diatom contribution to total phytoplankton in 1992 and 1993 in the same area (Bustillos-Guzmán et al. 1995). Hence, potential influence of changing environmental conditions on phytoplankton can be hypothesized at 
the scale of the coastal areas of the Ligurian Sea. However, along the French, Italian and Spanish coasts, a decrease in chl a concentrations and a shift from siliceous to non-siliceous phytoplankton caused by reduced winter nutrient replenishment of the surface layer are probably damped and complicated by local human pressure, which increases the external nutrient inputs.

Remotely sensed ocean color is a unique tool for determining phytoplankton biomass at the basin scale. However, our knowledge of interannual variability of sea surface chl a derived from remote sensing is limited by the fact that CZCS ceased operations in 1986 and the Sea-viewing Wide Field-of-view Sensor [SeaWiFS] was launched in late 1997. In the western Mediterranean, the CZCS spatial and temporal coverage was low, especially in winter, therefore, a study of interannual variability of phytoplankton biomass was not possible (Morel \& André 1991). Nevertheless, on the one hand, daily CZCS images showed that chl a was $>1.5 \mu \mathrm{g} \mathrm{l}^{-1}$ near Calvi and along the western Corsican coast in early May 1981 (image of 6 May 1981 in Morel \& André 1991). On the other hand, the SeaWiFS image of April 1998 (Turley et al. 2000) showed a westeast trend in surface chl $a$ in the Ligurian Sea, with values ranging between 0.2 and $0.3 \mu \mathrm{g} \mathrm{l}^{-1}$ along the western Corsican coast. Even if the remotely sensed data concern offshore chl $a$ and our study focuses on coastal waters, the May 1981 CZCS chl a values are consistent with our hypothesis that phytoplankton blooms took place along the western Corsican coast until 1986, and the April 1998 SeaWiFS values are similar to our field data (0.05 to $\left.0.18 \mu \mathrm{g} \mathrm{l}^{-1}\right)$.

The trend of increasing oligotrophy of the surface layer along the western Corsican coast during the winter-spring period is in contradiction with the overall trend of increasing eutrophication in many coastal Mediterranean areas (UNEP/FAO/WHO 1996), and of increasing nitrate and phosphate concentrations in the deep waters of the western basin (Bethoux et al. 1998). These opposite trends probably reflect: (1) a sharp difference between coastal areas where the supply of nutrient is controlled by hydrodynamic processes (like the western Corsican coast) and where it results from a combination of both natural mixing processes and human activities; and (2) the larger geographical extent of the areas belonging to the second type of systems, and exposed to varying degrees of eutrophication. The first type of systems (e.g. western Corsican coast) offers sites where ecosystem responses to climate change can be studied, whereas changes in the second type of system mostly reflect local perturbations.

The present study is a first attempt at describing and understanding long-term changes that occurred in a Mediterranean coastal ecosystem, in response to changing climatic and environmental conditions. It confirms that the Mediterranean reacts rapidly to external perturbations, and emphasizes the need of long-term monitoring programs. It also shows that only a small number of coastal sites, with very specific physical characteristics, can be used to study the responses of marine ecosystems to the changing climate.

Acknowledgements. This work was supported by 2 'Actions Concertées' programs and several FRFC grants. The fieldwork was performed at STARESO (Oceanographic Field Station of the University of Liège, in Calvi, Corsica) where we thank the staff for their logistic support. We are grateful to Costa Frangoulis for efficient assistance in the field in 1997 and 1998, and to Jean-Paul Giorgetti and Jean-Pierre Palauqui (Météo-France) for their help in providing the meteorological data from the airports. Temperature data were partly provided by STARESO. Three anonymous reviewers are thanked for their thorough and helpful comments on the manuscript. J.-H.H. is a research associate of the Belgian National Fund for Scientific Research (FNRS).

\section{LITERATURE CITED}

Antoine D, Morel A, André JM (1995) Algal pigment distribution and primary production in the eastern Mediterranean as derived from coastal zone color scanner observations. J Geophys Res 100:16193-16209

Atlas EL, Hager SW, Gordon LI, Park PK (1971) A practical manual for use of the Technicon Autoanalyzer in seawater nutrient analyses; revised. Technical Report 215. Department of Oceanography, Oregon State University

Barlow RG, Mantoura RFC, Gough MA, Fileman TW (1993) Pigment signatures of the phytoplankton composition in the North eastern Atlantic during the 1990 spring bloom. Deep-Sea Res 40:459-477

Bethoux JP, Gentili B (1996) The Mediterranean Sea, coastal and deep-sea signatures of climatic and environmental changes. J Mar Syst 7:383-394

Bethoux JP, Gentili B (1999) Functioning of the Mediterranean Sea: past and present changes related to freshwater input and climate changes. J Mar Syst 20:33-47

Bethoux JP, Gentili B, Raunet J, Tailliez D (1990) Warming trend in the western Mediterranean deep water. Nature 347:660-662

Bethoux JP, Gentili B, Tailliez D (1998) Warming and freshwater budget change in the Mediterranean since the 1940 s, their possible relation to the greenhouse effect. Geophys Res Lett 25:1023-1026

Boucher J, Ibanez F, Prieur L (1987) Daily and seasonal variations in the spatial distribution of zooplankton populations in relation to the physical structure in the Ligurian front. J Mar Res 45:133-173

Bradley RS, Diaz HF, Eischeid JK, Jones PD, Kelly PM, Goodess CM (1987) Precipitation fluctuations over northern hemisphere land areas since the mid-19th century. Science 237: 171-175

Brzezinski MA, Phillips DR, Chavez FP, Friederich GE, Dugdale RC (1997) Silica production in the Monterey, California, upwelling system. Limnol Oceanogr 42:1694-1705

Bustillos-Guzmán J, Claustre H, Marty JC (1995) Specific phytoplankton signatures and their relationships to hydrographic conditions in the coastal northwestern Mediterranean Sea. Mar Ecol Prog Ser 124:247-258 
Claustre H, Marty JC, Cassiani L (1989) Intraspecific differences in the biochemical composition of a diatom during a spring bloom in Villefranche-sur-Mer Bay, Mediterranean Sea. J Exp Mar Biol Ecol 129:17-32

Claustre H, Kerhervé P, Marty JC, Prieur L, Videau C, Hecq JH (1994) Phytoplankton dynamics associated with a geostrophic front: ecological and biogeochemical implications. J Mar Res 52:711-742

Coste B, Gostan J, Minas HJ (1972) Influence des conditions hivernales sur les productions phyto- et zooplanctoniques en Méditerranée Nord-Occidentale. 1. Structures hydrologiques et distribution des sels nutritifs. Mar Biol 16: 320-348 (in French with English abstract)

Cruzado A (1985) Chemistry of Mediterranean waters. In: Margalef R (ed) Western Mediterranean. Pergamon Press, Oxford, p 126-147

Della Vedova B, Foucher JP, Pellis G, Harmegnies F, MEDRIFF Consortium (1995) Heat flow measurements on the Mediterranean ridge indicate transient processes of heat transfer between the sediment and the water column. Rapp Comm Int Mer Médit 34:100

Duarte CM, Agustí S, Kennedy H, Vaqué D (1999) The Mediterranean climate as a template for Mediterranean marine ecosystems: the example of the NE Spanish littoral. Prog Oceanogr 44:245-270

Estrada M (1996) Primary production in the northwestern Mediterranean. Sci Mar 60:55-64

Estrada M, Margalef R (1988) Supply of nutrients to the Mediterranean photic zone along a persistent front. Oceanol Acta 9(SP):133-142

Estrada M, Vives F, Alcaraz M (1985) Life and the productivity of the open ocean. In: Margalef R (ed) Western Mediterranean. Pergamon Press, Oxford, p 148-197

Estrada M, Marrasé C, Latasa M, Berdalet E, Delgado M, Riera T (1993) Variability of deep chlorophyll maximum characteristics in the Northwestern Mediterranean. Mar Ecol Prog Ser 92:289-300

Estrada M, Varela RA, Salat J, Cruzado A, Arias E (1999) Spatio-temporal variability of the winter phytoplankton distribution across the Catalan and North Balearic fronts (NW Mediterranean). J Plankton Res 21:1-20

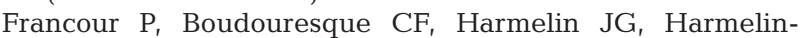
Vivien ML, Quignard JP (1994) Are the Mediterranean waters becoming warmer? Information from biological indicators. Mar Pollut Bull 28:523-526

Galil BS (1993) Lessepsian migration: new findings on the foremost anthropogenic change in the Levant basin fauna. In: Della Croce NFR (ed) Symposium Mediterranean seas 2000. ISAM, Genova University, p 307-318

Garcia-Gorriz E, Carr ME (1999) The climatological annual cycle of satellite-derived phytoplankton pigments in the Alboran Sea. Geophys Res Lett 26:2985-2988

Goffart A (1992) Influence des contraintes hydrodynamiques sur la structure des communautés phytoplanctoniques du bassin Liguro-Provençal (secteur Corse). PhD thesis, Université de Liège (in French)

Goffart A, Hecq JH (1993) Control of phytoplankton development by nitrate availability in the Liguro-provençal basin (Western Mediterranean). In: Progress in Belgian Oceanography Research (Brussels, January 21-22, 1993). Royal Academy of Belgium, National Committee of Oceanology, Brussels, p 251-261

Goffart A, Hecq JH, Prieur L (1995) Contrôle du phytoplancton du bassin ligure par le front liguro-provençal (secteur corse). Oceanol Acta 18:329-342 (in French with English abstract)

Gordon LI, Jennings JC, Ross AA Jr, Krest JM (1993) A sug- gested protocol for continuous flow automated analysis of seawater nutrients (phosphate, nitrate, nitrite and silicic acid) in the WOCE Hydrographic Program and the Joint Global Ocean Fluxes Study. Methods Manual WHPO 911. WOCE Hydrographic Program Office, La Jolla, CA

Grillini CL, Lazzara L (1980) Ciclo annuale del fitoplancton nelle acque costiere del Parco Naturale della Marenna. II. Flora e variazioni delle comunità. G Bot It 114:199-215

Hecq JH, Gaspar A, Dauby P (1981) Caractéristiques écologiques et biochimiques de l'écosystème planctonique en baie de Calvi (Corse). Bull Soc R Sci Liège 11-12:440-445

Hoffmann L, Clarisse S, Detienne X, Goffart A, Renard R, Demoulin V (1988) Evolution of the populations of Cystoseira balearica (Phaeophyceae) and epiphytic Bangiophyceae in the Bay of Calvi (Corsica) in the last eight years. Bull Soc R Sci Liege 17:57-67

Hoffmann L, Renard R, Demoulin V (1992) Phenology, growth and biomass of Cystoseira balearica in Calvi (Corsica). Mar Ecol Prog Ser 80:249-254

Hopkins TS (1985) Physics of the sea. In: Margalef R (ed) Western Mediterranean. Pergamon Press, Oxford, p 100-125

Jacques G, Tréguer P (1986) Ecosystèmes pélagiques marins. Collection d'Ecologie, Masson, Paris

Jacques G, Minas HJ, Minas M, Nival P (1973) Influence des conditions hivernales sur les productions phyto- et zooplanctoniques en Méditérranée Nord-Occidentale. 2. Biomasse et production phytoplanctoniques. Mar Biol 23: 251-265 (in French with English abstract)

Jeffrey SW (1980) Algal pigment systems. In: Falkowski P (ed) Primary productivity in the sea. Plenum Press, New York, p 3-58

Jeffrey SW, Humphrey GF (1975) New spectrophotometric equations for determining chlorophylls $\mathrm{a}, \mathrm{b}, \mathrm{c}_{1}$ and $\mathrm{c}_{2}$ in higher plants, algae and natural phytoplankton. Biochem Physiol Pflanz 167:191-194

Jeffrey SW, Mantoura RFC, Wright SW (eds) (1997) Phytoplankton pigments in oceanography. Monogr Oceanogr Methodol. UNESCO, Paris

Latasa M, Bidigare RR (1998) A comparison of phytoplankton populations of the Arabian Sea during the spring intermonsoon and southwest monsoon of 1995 as described by HPLC-analyzed pigments. Deep-Sea Res 45:2133-2170

Legendre P, Legendre L (1998) Numerical ecology, 2nd English edn. Elsevier Science Publishers, Amsterdam

López S, Turón X, Montero E, Palacín C, Duarte CM, Tarjuelo I (1998) Larval abundance, recruitment and early mortality in Paracentrotus lividus (Echinoidea). Interannual variability and plankton-benthos coupling. Mar Ecol Prog Ser 172:239-251

Lorenzen CJ (1967) Determination of chlorophyll and phaeopigments: spectrophotometric equations. Limnol Oceanogr 12:343-347

Lorenzen CJ, Jeffrey SW (1980) Determination of chlorophyll in seawater: report of intercalibration tests. UNESCO Tech Pap Mar Sci 35

Mantoura RFC, Llewellyn CA (1983) The rapid determination of algal chlorophyll and carotenoid pigments and their breakdown products in natural waters by reverse-phase high performance liquid chromatography. Anal Chim Acta 151:297-314

Marbà N, Duarte CM (1997) Interannual changes in seagrass (Posidonia oceanica) growth and environmental change in the Spanish Mediterranean littoral zone. Limnol Oceanogr 42:800-810

Margalef R (1985) Introduction to the Mediterranean. In: Margalef R (ed) Western Mediterranean. Pergamon Press, Oxford, p 1-16 
Margalef R, Castellvì J (1967) Fitoplancton y producciòn primaria de la costa catalana, de julio de 1966 a julio de 1967 . Invest Pesq 31 491-502

Marty JC (ed) (2002) Studies at the DYFAMED (France JGOFS) time-series station, NW Mediterranean Sea. Deep-Sea Res 49

Marty JC, Chiaverini J, Pizay MD, Avril B (2002) Seasonal and interannual dynamics of nutrients and phytoplankton pigments in the western Mediterranean Sea at the DYFAMED time-series station (1991-1999). Deep-Sea Res 49:1965-1985

Millot C (1999) Circulation in the western Mediterranean Sea. J Mar Syst 20:423-442

Morel A, André JM (1991) Pigment distribution and primary production in the western Mediterranean as derived and modeled from coastal zone color scanner observations. J Geophys Res 96:12685-12698

Mura MP, Agustí S, Cebrián J, Satta MP (1996) Seasonal variability of phytoplankton biomass and community composition in Blanes Bay (1992-1994). Publ Espec Inst Esp Oceanogr 22:23-29

Nyffeler F, Prieur L (1972) Mesure des propriétés optiques de l'eau de mer: relations avec l'hydrologie et l'activité biologique. Rapp Comm Int Mer Médit 21:159-164

Officer CB, Rythere JH (1980) The possible importance of silicon in marine eutrophication. Mar Ecol Prog Ser 3:83-91

Palomera I, Olivar MP (1996) Nearshore ichthyoplankton off the Costa Brava (Northwest Mediterranean). Publ Espec Inst Esp Oceanogr 22:71-76

Pedrós-Alió C, Calderón-Paz JI, Guixa-Boixereu N, Estrada M, Gasol JM (1999) Bacterioplankton and phytoplankton biomass and production during summer stratification in the northwestern Mediterranean Sea. Deep-Sea Res 46: 985-1019

Pinca S, Dallot S (1995) Meso- and macrozooplankton composition patterns related to hydrodynamic structures in the Ligurian Sea (Trophos-2 experiment, April-June 1986). Mar Ecol Prog Ser 126:49-65

Por FD (1990) Lessepsian migration, an appraisal and new data. Bull Inst Oceanogr (Monaco) 7:1-10

Roether W, Manca BB, Klein B, Bregant D and 4 others (1996) Recent changes in eastern Mediterranean deep waters. Science 271:333-335

Rohling EJ, Bryden HL (1992) Man induced salinity and temperatures increases in the western Mediterranean deepwater. J Geophys Res 97:191-198

Samuel S, Haines K, Josey S, Myers PG (1999) Response of the Mediterranean Sea thermohaline circulation to ob-

Editorial responsibility: Otto Kinne (Editor),

Oldendorf/Luhe, Germany served changes in the winter wind stress field in the period. J Geophys Res 104:7771-7784

SCOR-UNESCO (1966) Determination of photosynthetic pigments in sea water. Monogr Oceanogr Methodol 1: $11-18$

Short FT, Neckles HA (1999) The effects of global climate change on seagrasses. Aquat Bot 63:169-196

Sournia A, Brylinski JM, Dallot S, Le Corre P and 3 others (1990) Fronts hydrologiques au large des côtes françaises: les sites-ateliers du programme Frontal. Oceanol Acta 13: 413-438 (in French with English abstract)

Thingstad TF, Rassoulzadegan F (1995) Nutrient limitations, microbial food webs, and 'biological C-pumps': suggested interactions in a P-limited Mediterranean. Mar Ecol Prog Ser 177:299-306

Travers M (1975) Le microplancton du golfe de Marseille: schéma du cycle annuel, répartitions horizontale et verticale. Tethys 6:713-726

Tréguer P, Le Corre P (1975) Manuel d'analyse des sels nutritifs dans l'eau de mer. Laboratoire d'Océanographie Chimique, Université de Bretagne Occidentale, Brest

Turley CM (1999) The changing Mediterranean Sea-a sensitive ecosystem? Progr Oceanogr 44:387-400

Turley CM, Bianchi M, Christaki U, Conan P and 6 others (2000) Relationship between primary producers and bacteria in an oligotrophic sea - the Mediterranean and biogeochemical implications. Mar Ecol Prog Ser 193:11-18

UNEP/FAO/WHO (1996) Assessment of the state of eutrophication in the Mediterranean Sea. MAP Tech Rep Ser 106, UNEP, Athens

Vaulot D, Partensky F, Neveux J, Mantoura RFC, Llewellyn CA (1990) Winter presence of prochlorophytes in surface waters of the northwestern Mediterranean Sea. Limnol Oceanogr 35:1156-1164

Venrick EL, Cummings SL, Kemper CA (1987) Picoplankton and the resulting bias in chlorophyll retained by traditional glass-fiber filters. Deep-Sea Res 34:1951-1956

Vidussi F, Marty JC, Chiavérini J (2000) Phytoplankton pigment variations during the transition from spring bloom to oligotrophy in the northwestern Mediterranean sea. Deep-Sea Res 47:423-445

Williams N (1998) The Mediterranean beckons oceanographers. Science 279:483-484

Williams R, Claustre H (1991) Photosynthetic pigments as biomarkers of phytoplankton populations and processes involved in the transformation of particulate organic matter at the Biotrans site $\left(47^{\circ} \mathrm{N}, 20^{\circ} \mathrm{W}\right)$. Deep-Sea Res 38: $347-355$

Submitted: December 15, 2000; Accepted: November 27, 2001 Proofs received from author(s): May 31, 2002 